\title{
DESIGN OF AUTOMATIC STAMPING MACHINE FOR DATE AND DASH CODE MARKING USING PNEUMATIC SYSTEM AND PLC CONTROLLER
}

\author{
Nanang Ali Sutisna ${ }^{1}$ and Reza Alfarisi Firmansyah ${ }^{2}$ \\ Mechanical Engineering, President University \\ JABABEKA Education Park Jl. Ki Hajar Dewantara, Cikarang Utara, Bekasi 17550 \\ 1email: nanang.ali@presiden.ac.id \\ email: rezaalfarisi30@gmail.com
}

\begin{abstract}
Abstrak
Penelitian ini dimaksudkan untuk merancang mesin otomatis untuk mencap kode tanggal dan tanda hubung pada karton induk untuk kemasan blister-pack. Kuantitas proses manual yang ada dalam memproduksi master carton tidak sesuai dengan tuntutan, oleh karena itu diperlukan mesin yang meningkatkan proses produksi dengan karakteristik sebagai berikut: cepat, mudah digunakan dan dirawat, serta terjangkau untuk mendukung program penghematan biaya. Desain menggunakan sistem pneumatik dengan pengontrol PLC untuk mengotomatisasi proses.
\end{abstract}

Kata kunci: Proses Pengemasan, Otomasi, Penumatic, PLC Controller

\section{Abstract}

The research is meant to design an automatic machine for stamping the date and dash code on the master carton for the packaging of the blister-pack. The quantity of existing manual process in producing the master carton does not meet with the demands, therefore, it needs a machine that improve the production process with the following characteristic: fast, easy to use and maintain, and also affordable in order to support the cost saving program. The design uses pneumatic system with PLC controller to automate the process.

Keywords : Packaging Process, Automation, Penumatic, PLC Controller

\section{Introduction}

The ABC company produces many variety of toys such as Fashion Dolls, Match Box, Play Board and Die Cast Car Toys with Production Plant around the world. The Indonesian plant producing Die Cast Car Toy and it have 2 million cars each week in demands. In the process of assortment of product the company has 2 different packaging, the first packaging named as blister car pack, the function is to be the container of the DIE-CAST Car Toy and also as the commercial purpose in marketing the product to the customer. The second packaging is master carton pack, the function is to be the container of 12 pack of blister car pack in delivering to the market/customers. Blister car packaging itself could contain until 5 cars for each blister pack carton and it has automatic processes by the Auto-Packing machine to reach the target of the demands, Auto-Packing machine works for divide the cars to each design of blister pack and giving the date code to the blister pack carton. The problem is master carton packaging is still producing by manual processes for forming the master carton and giving the date and dash code stamping to the master carton. Giving the date and dash code stamping in actual the operators are only able to produce 1372 master carton for each shift, meanwhile the demands of the company are 2 million cars each week. In that case the company at least need to produce 33.500 master cartons each week or 5600 master carton each shift. Because the demand of the master carton is 5600 master cartons per shift. This design is developed to fulfill the program of cost saving and optimizing the process of assortment especially 
in giving the date and dash code for master carton in order to gaining the productivity and also the profit of the company.

\section{Terminology}

\section{Engineering Design}

ABET (Accreditation Board for Engineering and Technology) states that "engineering design is the process of devising a system, component, or process to meet desired needs". Then in a design it is good also if we include the variety of realistic constraints that will arise such as, safety, economic, aesthetic, etc. Depth of design is also divided into several classes depending on the reasons and how to build a design. The class is divided into 3 levels namely adaptive design, develop design, and new design [1].

\section{Pneumatic System}

In the manufacturing department many utilities are in use such as electricity, natural gas, water, and also air, pneumatic is a system that utilizes the power carried by the air in a tool. Pneumatic system is widely used in Industrial Automation because it is quite simple and reliable, pneumatic is also often used because it quiet cheap technology in comparison with other technologies such as hydraulic or electric motor in addition to the unction of moving a very light load for example it will spend much cost if use in hydraulic or electric motor. Based on the figure above, Pneumatic is simpler if compared with hydraulic and electric system, give more profit on the capital cost and maintain [2].

\section{Programmable Logic Controller (PLC)}

Programmable logic controller (PLC) is a special form of microprocessor-based controller that uses a programmable memory to store instructions and to implement functions such as logic, sequencing, timing, counting and arithmetic in order to control machines and processes [3].

PLCs are similar to computers but whereas computers are optimized for calculation and display tasks, PLC are optimized for control tasks and the industrial environment. Since the PLCs are:

1. Rugged and designed to withstand vibrations, temperature, humidity and noise.

2. Have interfacing for inputs and outputs already inside the controller.

3. Are easily programmed and have an easily understood programming language which is primarily concerned with logic and switching operations.

\section{Cycle Time}

In designing the machine using the pneumatic system the first thing should to determine is the pressure supply to lift the load, basically the force of the actuator should be higher than the Load. It should be noted that the fluid pressure has no effect to the cylinder speed [4], the speed is determined from the Area of the piston and the flow-rate so the total time would be the volume of the air consumption at distance that would be reach divided by the flow rate, below is the step to find cycle time:

1. Find the Volume from the air consumption

$$
V=Q \times d
$$

$$
\begin{aligned}
& \text { Where: } \\
& V: \text { The volume of air consumption }(l) \\
& Q: \text { The air consumption for each } \mathrm{cm}(l / \mathrm{cm})
\end{aligned}
$$


$d$ : The distance of the stroke moves $(\mathrm{cm})$

2. Find the cycle time

$$
t=\frac{V}{v_{a}}
$$

Where:

$t$ : The time $(s)$

$V$ : The volume $(l)$

$v_{a}:$ The flow rate $(l / s)$

\section{Bending Stress}

To calculating the construction of machine, it will consider about the stress of the material in which shape. Then at this design the critical point will be in the bending stress, the bending moment $M$ along the length of the beam can be determined from the moment diagram. Below is the formula of bending stress :

$$
\sigma_{\text {bending }}=\frac{M y}{I}
$$

where:

$\sigma_{\text {bending }}$ is bending stress $(M P a)$

$\mathrm{M} \quad$ is Moment $(\mathrm{Nmm})$

$y \quad$ is distance to neutral axis $(\mathrm{mm})$

$I \quad$ is Area of inertia $\left(\mathrm{mm}^{4}\right)$

The bending moment at any locations along the beam can be used to calculate the bending stress over the beam's cross section at that location. The bending moment varies over the height of the cross section according the formula below:

$$
\begin{aligned}
& M_{x}=-F l_{y} \\
& \text { where: } \\
& M_{x} \quad \text { is the Moment along the beam }(\mathrm{Nmm}) \\
& F \quad \text { is the Force that distributed to the beam }(\mathrm{N}) \\
& L_{y} \quad \text { is the distance of the force }(\mathrm{mm})
\end{aligned}
$$

The Area moment of the inertia is a property of two-dimensional plane shape which characterizes its deflection under loading [5]. To determine the moment are of inertia is depends on the shape of the area, for the rectangular area will use the formula below

$$
I=\frac{1}{12} b h^{3}
$$

where:

$I \quad$ is Area of inertia $\left(\mathrm{mm}^{4}\right)$

$b \quad$ is breadth $(\mathrm{mm})$

$h \quad$ is the height $(\mathrm{mm})$ 


\section{Allowable Bending Stress}

$$
\text { Allowable } \sigma_{\text {bending }}=\frac{\text { yield strength }}{\text { safety factor }}
$$

\section{Deflection as a result from bending moment}

$$
\text { Deflection }=\frac{F \times\left(L^{3}\right)}{3 \times E \times l}
$$

\section{Allowable Deflection}

$$
\text { allowable deflection }=\text { coefficient deflection } \times \text { Length }
$$

Comparison between the deflection and allowable deflection, the allowable deflection must be greater than the deflection.

$$
\text { allowable deflect > deflection }
$$

\section{Break Even Point}

Break-even point is to give an answer to the business such as "how much sales be decreased and the company still continues to be profitable". Break-even analysis is extremely important before starting a new product or new decision in investing a tools or machine. Break-even analysis based on categorizing production costs between those which are variable and those which are fixed [6]. Below is the formula to calculate the break-even point

$$
B E P=\frac{F C}{C S-V C}
$$

Where:

- $B E P$ is Break-even point

- $F C$ is Fix cost

- $C S$ is the profit

- $V C$ is the variable cost

\section{Methodology}

\section{Requirement Study}

The requirements will be very important on analysis that will be performed. Tabel 1 below are the requirements of the company:

Table 1. Requirement

\begin{tabular}{|l|l|l|}
\hline No & Description & Requirements \\
\hline 1 & Giving date and dash code automatically & Machine \\
\hline 2 & Production target 5600/shift & Fast \\
\hline 3 & Easy to Use and Maintain & Operable \\
\hline
\end{tabular}




\section{Conceptual and Detailed Design}

Then in order to meet the requirements, the researcher develop the conceptual design of the machine to become the detailed design using CATIA V5 software to realize the imagination into a computer aided design (CAD). This design is one of development design from the stamping machine for brass. The detail of design is shown in figure 1 below:

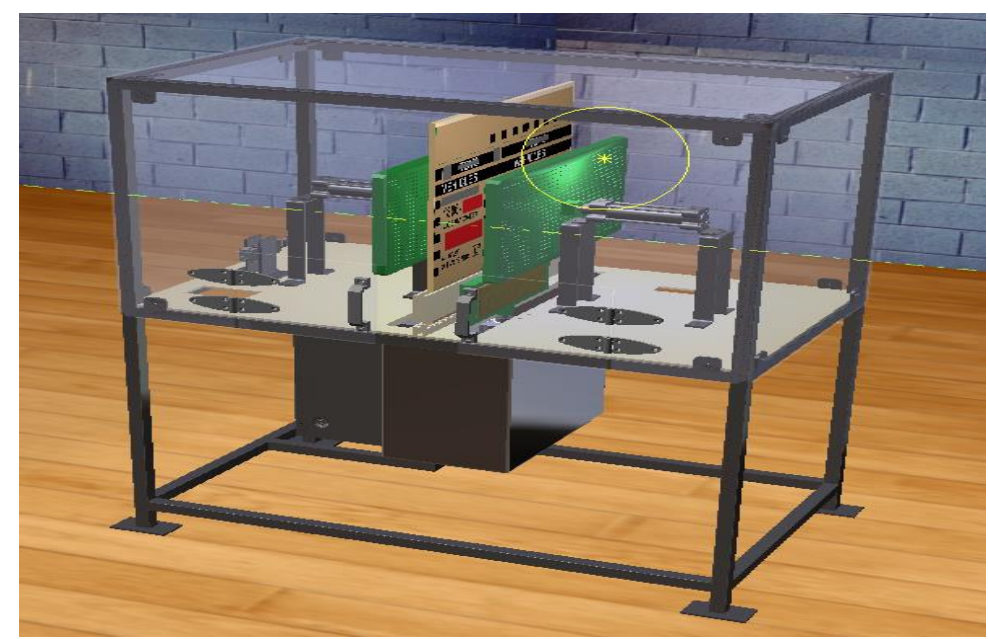

Figure 1. Ideas of design

From the requirements and idea of design the researchers choose the tools for the movement system by using linear actuator, then for the working sequence would be:

Table 1 Working sequences

\begin{tabular}{|c|l|l|l|}
\hline & Type of Work & \multicolumn{1}{|c|}{ Tools } & \multicolumn{1}{c|}{ Distance of Movement } \\
\hline 1 & Marking & Double Acting Cylinder & $250 \mathrm{~mm}$ from initial position \\
\hline 2 & Un-marking & Double Acting Cylinder & $250 \mathrm{~mm}$ from Marking position \\
\hline 3 & Stamping & Double Acting Cylinder & $70 \mathrm{~mm}$ from initial position \\
\hline 4 & Un-stamping & Double Acting Cylinder & $70 \mathrm{~mm}$ from Stamping position \\
\hline
\end{tabular}

\section{PLC Programming}

From the Data collection the researcher creates the program to run the pneumatic system as the expected working sequences of the machine. The researcher has decided to using the Programmable Logic Control (PLC) to controlling the working sequences, the language of the machine is using binary code signal, binary code uses to give the signals to the output memory of the PLC. To realize that binary code the researcher using the Function Block Diagram to inputting 
the program. From those, the researcher will create Block Function methods for choosing the way to inputting the program methods by using FESTO Fluid simulator. The function would be:

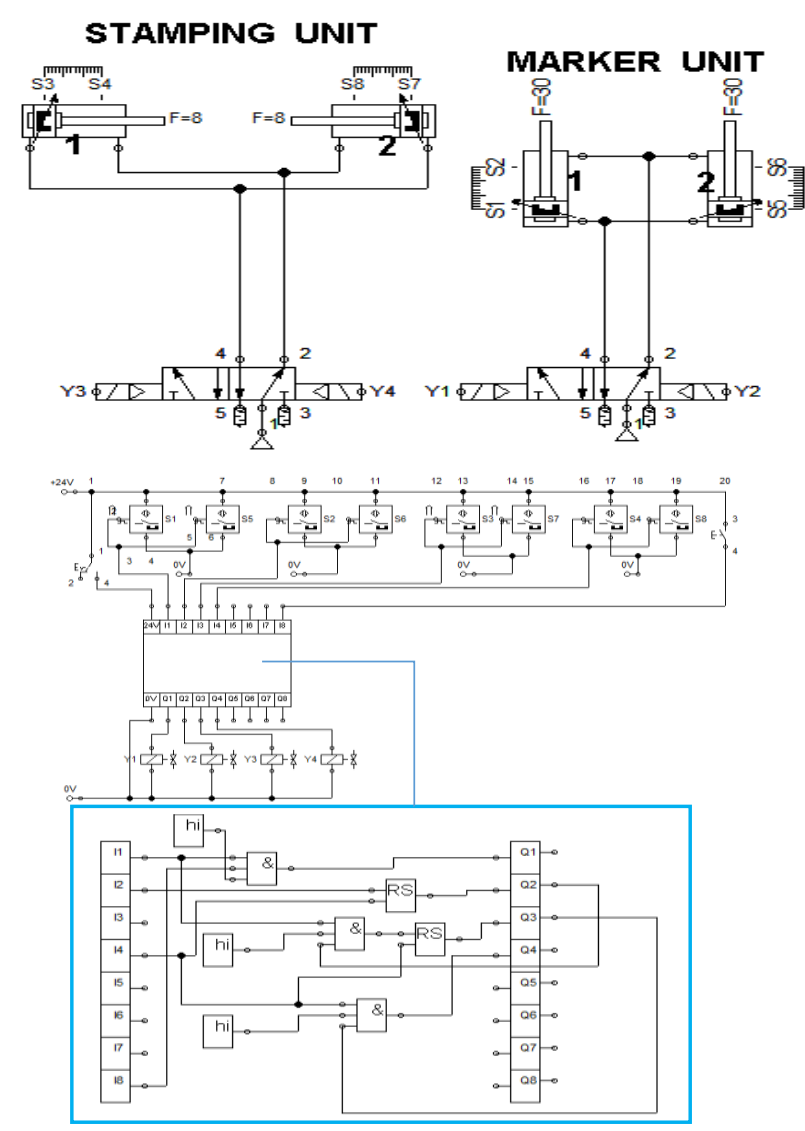

Figure 1. Program input of PLC

To calculate the cycle time there are some required data that will be need. The data are pressure, flow rate from the valve, area of every sequences. The details of data required will be listed below:

Pressure ( $\mathrm{P}$ ) : 4 bars

Flow Rate $\left(v_{a}\right) \quad: 3101 / \mathrm{min}$ or $5.161 / \mathrm{s}$

Marker sequence is using Double acting cylinder to carrying the marker batch until $250 \mathrm{~mm}$ from initial position, so the calculation would be shown below:
Distance $(\mathrm{s}) \quad=25 \mathrm{~cm}^{\prime}$
Mass $(\mathrm{m}) \quad=0.81 \mathrm{~kg}$
Diameter of Bore $(\mathrm{d})=0.032 \mathrm{~m}$
Area $(\mathrm{A}) \quad=0.000804 \mathrm{~m}^{2}$

From the figure above the researchers know that there is acceleration at this system from the static condition into steady. But usually the acceleration has the small value so it will not consider to this calculation indeed there is acceleration. The calculation when the flow is steady would be:

a. Find the Volume from the air consumption

$$
\begin{aligned}
V & =Q \times d \\
V & =0.027 \frac{\mathrm{l}}{\mathrm{cm}} \times 25 \mathrm{~cm} \\
V & =0.675 \mathrm{l}
\end{aligned}
$$


b. Find the cycle time of movement

$v_{a}$ is the flow of air from the valve, in this calculation the flow would be controlled by the tool called as "flow control" then it would be open the until $30 \%$ aperture, as we know from the given condition the flow of air Figure 4. 15 Free body diagram and graph of Marking sequence (a) Simple system of marking sequence (b) Graph for P1 is Pin, P2 is Pout, and speed [4] 59 from the valve is $5.16 \mathrm{l} / \mathrm{s}$ so the flow after controlled by flow control with $30 \%$ aperture would be $1.16 \mathrm{l} / \mathrm{s}$. then the calculation for the cycle time would be:

$$
\begin{aligned}
t & =\frac{V}{v_{a}} \\
t & =\frac{0.675 l}{5.16 l / s \times 0.30} \\
t & =0.436 \mathrm{~s}
\end{aligned}
$$

So from the discussion the researcher will calculate the total cycle time from every sequence and cycle time of the operator to become the total cycle time of process, the total cycle time would be:

$$
\begin{gathered}
\Sigma t=t_{\text {Machine }}+t_{\text {Operator }} \\
t_{\text {Machine }}=t_{\text {Marking }}+t_{\text {Unmarking }}+t_{\text {Stamping }}+t_{\text {Unstamping }}
\end{gathered}
$$

From the equation of $\boldsymbol{\Sigma} \boldsymbol{t}$ above the researcher could find cycle time of machine and operator. The cycle time of operator has been simulated by the researcher for loading-unloading then press the push button and the result is about $2.5 \mathrm{~s}$, then the table of the total cycle time of machine will be shown in the bale below:

Table 2 Cycle time of sequences

\begin{tabular}{|c|c|c|c|}
\hline Movement & $\begin{array}{c}\text { Distance } \\
(\mathbf{c m})\end{array}$ & $\begin{array}{c}\text { Air consumption } \\
\text { for full stroke }(\mathbf{L})\end{array}$ & Cycle Time $\mathbf{( s )}$ \\
\hline Marking & 25 & 0.675 & 0.436 \\
\hline Un-Marking & 25 & 0.425 & 0.274 \\
\hline Stamping & 7 & 0.189 & 0.122 \\
\hline Un-Stamping & 7 & 0.119 & 0.076 \\
\hline
\end{tabular}

\section{Machine Construction Analysis}

For calculating the construction of machine, the researcher has chosen the most critical part that happens by force of the stamping-un-stamping actuator. Then to simplify the cases, the free body diagram would be shown in the figure below:

Given:

Length $=220 \mathrm{~mm}$

Thickness (b) $=10 \mathrm{~mm}$

Width (h) $=30 \mathrm{~mm}$

$\mathrm{F}=80.4 \mathrm{~N}$

Yield strength $=215 \mathrm{Mpa}$

Safety factor $=8$

Coefficient of deflection $=0.0005$ 
Find Bending Stress

$$
M x=-80.4 \times 220
$$

$M x=-17688 \mathrm{Nmm}$

Area Momen of Inertia

$$
\begin{aligned}
& I=\frac{1}{12} \times(10) \times(30)^{3} \\
& I=\frac{1}{12} \times(10) \times 27000 \\
& I=\frac{1}{12} \times 270000 \\
& I=225000 \mathrm{~mm}^{4}
\end{aligned}
$$

Bending stress

$$
\begin{aligned}
& \sigma_{\text {bending }}=\frac{17688 \mathrm{Nmm} \times 15 \mathrm{~mm}}{22500 \mathrm{~mm}^{4}} \\
& \sigma_{\text {bending }}=11.792 \mathrm{~N} / \mathrm{mm}^{4}
\end{aligned}
$$

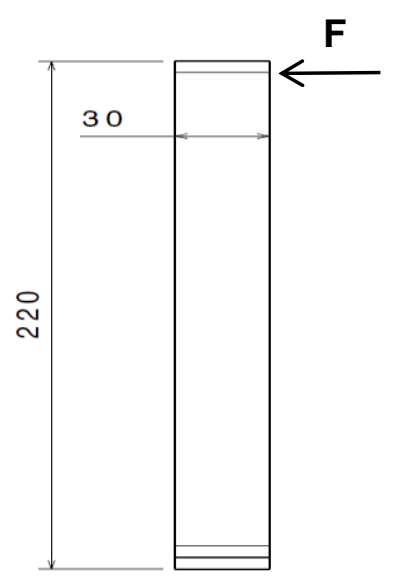

Figure 2 Free body diagram of construction

The yield strength of the material (SS304) is $215 \mathrm{MPa}$. Comparing bending stress with the allowable stress, in this case the safety factor chosen from the characteristic of the condition, this machine is one type of live load condition, then the amount of safety factor for live load is 8 .

$$
\begin{aligned}
& \text { allowable } \sigma_{\text {bending }}=\frac{215}{8} \\
& \text { allowable } \sigma_{\text {bending }}=26.875 \\
& \text { allowable } \sigma_{\text {bending }}>\sigma_{\text {bending }} \\
& 26.875>11.792
\end{aligned}
$$

Deflection from moment bending

$$
\begin{gathered}
\text { deflection }=\frac{80.4 \mathrm{~N} \times(220 \mathrm{~mm})^{3}}{3 \times 193000 \mathrm{MPa} \times 22500 \mathrm{~mm}^{4}} \\
\text { deflection }=0.065 \mathrm{~mm}
\end{gathered}
$$

Allowable Deflection

$$
\text { allowable deflection=coefficient deflection } \times \text { Length }
$$

Coefficient deflection is taken from the deflection limits for general machine [8] is 0.0005 in/in.

$$
\text { allowable deflection } \quad=0.0005 \times 220 \mathrm{~mm}
$$

$$
=0.11 \mathrm{~mm}
$$

Comparison between the deflection and allowable deflection, the allowable deflection must be greater than the deflection.

allowable deflection $>$ deflection

$0.11 \mathrm{~mm}>0.065 \mathrm{~mm}$ 


\section{Cost comparison between current and improvement processes}

At this step the researcher would to analyze the cost when the company use the current process and the improvement process, after that it would compared to get the break event point when the company investing the machine.

A. Current process

1. Number of operator when using manual operation

$$
\begin{aligned}
& \text { Person }=\text { Target of Production } / \text { Value of Production } \\
& \text { Person }=5600 \text { pcs } / \text { shift } 1372 \text { pcs } / \text { shift } \\
& \text { Person }=4.08 \approx 5 \text { persons }
\end{aligned}
$$

2. Expense of current process cost

$$
\begin{aligned}
\text { Salary of operator } & =\text { IDR } 4,000,000(R p) \\
\text { Cost }_{\text {current }} & =R p \times \text { Perso } n \\
\text { Cost }_{\text {current }} & =I D R 4,000,000 \times 5 \text { persons } \\
\text { Cost }_{\text {current }} & =I D R 20,000,000
\end{aligned}
$$

B. Improvement process

The improvement process will be using the machine called as "Automatic Stamping Machine for Date and Dash Code marking using Pneumatic System and PLC Controller", the total cycle time when using this machine is 4 seconds per master carton. Below is the calculation of total production when using the machine and the expense cost to meet the demands:

1. Total production when using the machine

Total Production=twork $\mathrm{t}$ machine

Total Production $=8$ hours $\times 3600$ seconds 4 seconds

Total Production=7200 pcs/shift

2. Number of Operator when using the machine

Person=Target of Production/Value of Production

Person $=56007200$ Person $=0.77 \approx 1$ person

3. Expense of improvement process cost

Costimprovement $=R p \times$ Person

Costimprovement $=I D R 4,000,000 \times 1$ person

Costimprovement $=I D R$ 4,000,000 69

The comparison here is to calculate the cost saving after using the improvement process. At this calculation also consist of the break event point after investing the machine cost, the fix cost here means the cost of investing the machine, the variable cost here is 0 , and the profit here is from the value of cost saving below is the calculation:

1. Cost saving

Cost Saving $=I D R$ 20,000,000-IDR 4,000,000

Cost Saving $=I D R \quad 16,000,000 /$ month

2. Break Event Point

$B E P=I D R$ 39,797,024.15 - IDR 16,000,000

$B E P=2.49$ Months 


\section{Graph of Break Event Point}

\section{Graph of BEP}

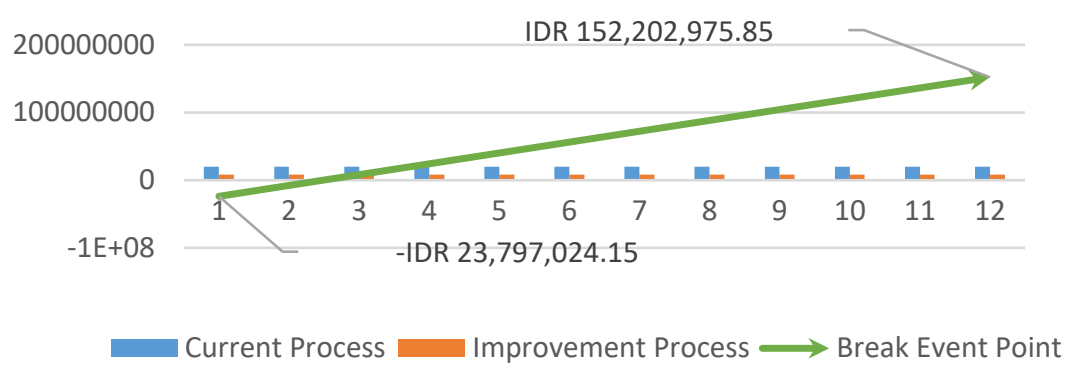

\section{Summary}

The design of automatic stamping machine under study from construction point of view is safe based on the calculation of bending stress applied to the main column. The machine uses penumatic system with PLC controller make it fast, easy to use and maintain.

From break event point calculation, the machine give very good cost saving since it built at affordable price and gives significant time saving.

\section{References}

[1] Haik, Y., \& Shahin, T. M. (2010). Engineering design process: Second edition. Mason, OH: Cengage Learning.

[2] Practical Guide to Pneumatics eBook. (n.d.). Retrieved March 25, 2018, from https://library.automationdirect.com/practical-guide-to-pneumatics/\#

[3] Bolton, W., (2006). Programmable Logic Controllers: Fourth edition. Burlington, ELSEVIER.

[4] Parr, A., (1998). Hydraulics and Pneumatics. Burlington, Butterworth-Heinemann.

[5] Gere M. J. (2004). Mechanics of Materials: Sixth edition. Belmont, Thompson-Learning.

[6] Mihaela, A., Elena, C., Break-Even in the decision-making process, Challenges of the Knowledge Society. Finance and Accounting, (2015), PP. 779-783.

[7] Information from from http://asm.matweb.com/search/SpecificMaterial.asp?bassnum=mq304a. Retrieved March 25, 2018,

[8] Khurmi, R. S., \& Gupta, J. K. (2004). A textbook of machine design. New Delhi: Eurasia Publishing House.

[9] Practical Guide to Pneumatics eBook. (n.d.). Retrieved March 25, 2018, from https://library.automationdirect.com/practical-guide-to-pneumatics/\# 